\title{
WASTE MANAGEMENT AT THE END OF THE STONE AGE
}

\author{
FILIP HAVLÍČEK ${ }^{1}$, MARTIN KUČA $^{2}$ \\ ${ }^{I}$ Dep. of Environmental Studies, Masaryk Uni., Brno, Czech Republic, e-mail: \\ bilbo@mail.muni.cz \\ ${ }^{2}$ Town Museum Moravský Krumlov, Moravský Krumlov, Czech Republic, e-mail: \\ makku@email.cz
}

Received: $19^{\text {th }}$ February 2017, Accepted: $22^{\text {th }}$ May 2017

\section{MotTo:}

The unconsciousness of every culture is particularized in its waste.

Thomas Hylland Eriksen

\begin{abstract}
This article describes examples of waste management systems from archaeological sites in Europe and the Middle East. These examples are then contextualized in the broader perspectives of environmental history. We can confidently claim that the natural resource use of societies predating the Lower Palaeolithic was in equilibrium with the environment. In sharp contrast stand communities from the Upper Palaeolithic and onwards, when agriculture appeared and provided opportunities for what seemed like unlimited expansion.

Keywords: Waste, waste management, Neolithic, Chalcolithic, cleanliness, environmental history
\end{abstract}

\section{INTRODUCTION}

Every individual as well as every human society produces waste; therefore, it is remarkable how few studies have been dedicated to gaining a deeper understanding of the relationship between humans and waste. Waste, in the broadest sense of the word, is produced by all types of life; it is also a part of the relationships between biotic organisms and their environment. Nonetheless, for us, human beings, waste is relegated to the margins of our world. Waste is a permanent and practically ubiquitous category of things.

Humankind's propensity for producing significantly more waste than other animals is explained by the fact that people adapt to their environments not only through biological evolution, but also with the help of culture and artefacts; therefore, humans produce more waste than animals, which do not make any artefacts. With greater technological advancements and population growth (mainly as a result of a settled way of life) the amount of produced artefacts as well as waste has grown exponentially from prehistoric times until the present. ${ }^{1}$ Understandably, settled societies anchored in one specific place over an

\footnotetext{
${ }^{1}$ The Industrial Revolution can be considered a watershed moment, when the amount and variability of waste began to significantly diversify.
} 
extended period of time produce more waste than nomadic hunter-gatherer societies; the most likely explanation is that in settled societies the burdens associated with mobility largely fall to the wayside.

At the beginning of Neolithic Age the greatest socioeconomic change to have taken place in history up to that point occurred - that is, the transition from a hunter-gatherer economy to planned agriculture and animal herding. The Neolithic Demographic Transition (NDT) that the settled way of life caused sparked changes from which there was no way back. Another likely consequence of the NDT was the development of social practices associated with higher population densities and the reflection of this environmental change on human health (Bocquet-Appel \& Bar-Yosef, 2008).

Whether the Neolithic Revolution was driven by society's inner needs, was a side effect of changes in ideology or religion (Mithen, 2011; Cauvin \& Watkins, 2000), or was the product of external natural pressures, such as adaptation to climate change (Richerson et al., 2001) or declining food sources (Martin, 1984), the hunter-gatherer economy was replaced by one based on agriculture and livestock breeding.

Of the many well-known differences between hunter-gather societies and agricultural societies there is one that sticks out in particular and is of great importance for this article - the organized disposal of waste, which Ofer Bar-Yosef and Richard Meadow have described as a typical feature of settled societies (Bar-Yosef \& Meadow, 1995). ${ }^{2}$ On the basis of these differences, we shall describe waste management phenomena in the Neolithic and Chalcolithic, which, we assume, reflect older Pleistocene origins.

\section{DEFINING AND CATEGORIZING WASTE}

Bjørnar Olsen writes that in the social sciences there is a resurgence of interest in studying objects and material to understand society through design, landscape, modern material culture, and so on (Olsen, 2010). One focus of this renewed interest has been on studying ordinary household waste, which processual archaeologists began doing in the 1960s.

Waste and the societies that create it cannot be studied as separate entities; they must be viewed together as a whole. Evžen Neustupný notes that waste deposits contain information that is fundamental "for understanding the spatial arrangement of elements of archaeological sources in many prehistoric periods" (Neustupný, 1998; 39).

Here, it is necessary to define several terms to avoid later misunderstandings about different categories of waste. Even though categorizing waste can be a very fluid affair that often cannot provide clear-cut definitions, it will be useful to at least provide a broad description of different types of waste. We shall use the term waste to refer to material that is permanently and intentionally thrown away with no further plans for its use. Thus, waste is material that could be fully discarded because its reuse was impossible or would require an excessive amount of energy. The term rubbish (see Thompson's "rubbish theory") refers to objects that have momentarily lost their value, but which may imaginably be of use again in the future.

Examples of recycling and reuse can be discerned in the historical period at the center of our study. We hypothesize that the more energy is initially invested in producing an artefact,

\footnotetext{
${ }^{2}$ George P. Murdock (1945) included on his list of universal characteristics of every human society attitudes towards cleanliness, which are closely related to waste management practices. In another article I have examined waste management in Paleolithic hunter-gatherer societies (Havlíček, 2015), providing a counterargument to the existence of such a historical watershed with the emergence of settlements.
} 
the greater the likelihood that this object will be defined as rubbish. ${ }^{3}$ We assume that this category will include worn-out and broken stone artefacts, considering the fact that stone ${ }^{4}$ as a raw material is hard to recycle or reuse. ${ }^{5}$ This phenomenon has been observed at the Neolithic site of Bylany, where rubbish occurs rarely in waste deposits (Květina, 2010).

As Květina notes (2010), in pre-industrial societies recycling (or reuse) was limited to worn-out vessels or large fragments thereof, metal or ground stone tools, or broken instruments, all materials that we could consider rubbish.

In the Neolithic and Chalcolithic Ages, we can find an array of waste-like material consisting mainly of compostable kitchen waste ${ }^{6}$ animal and human excrement (which can be reused as fertilizer); ashes, which also can be reused for many purposes, including fertilizing (Guttmann et al., 2006) and washing (Havlíček, 2017; in press); and other defective household items, ${ }^{7}$ as well as waste from artefact production and building materials (Květina, 2010) (Fig. 1). ${ }^{8}$

\section{Fig. 1: Graph 1 (Author: Filip Havlíček)}

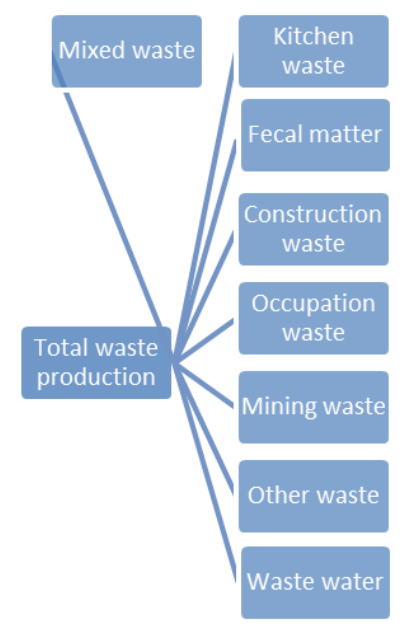

\footnotetext{
${ }^{3}$ As a rule, people do not work more than they have to. This principle, which Hayden \& Cannon (1983) describe in their ethno-archeological work, can be considered a constant feature in the human species.

${ }^{4}$ Ground tools could be reutilized more easily and therefore they may have ended up categorized as rubbish.

${ }^{5}$ Thanks to Vaquero's (2012) work on the reutilization of stone in the Paleolithic, we can assume that it did occur to some extent in the Neolithic and Chalcolithic.

${ }^{6}$ In many cases, one's man's waste can literally become another's treasure, and vice versa. Verhart and Wansleeben (1997) describe how the waste of one culture may become a valuable source of material in another (even if only of ritual importance). For example, seashells were used from the Paleolithic onward for making jeweler, but the same type of material was also discarded in large amounts to produce shell middens (køkkenmødding).
}

${ }^{7}$ Pottery is the most frequently discovered artefact by archeologists. It could be recycled, or reused, by grinding broken pottery shards and putting this material into pottery clay (Hložek et al., 2006).

${ }^{8}$ Tell settlements will be discussed below. 
M. B. Schiffer (1987) provides another definition, one that does not differentiate between rubbish and waste, but which defines waste as any object that cannot serve its original purpose or any other secondary one, and thus has introduced the terms primary refuse, secondary refuse, and de facto refuse, a classification which M. Kuna has developed further to include tertiary refuse (Neustupný, 1996; 496). On the basis of ethnological analogies, Schiffer (1987; 59-64) demonstrates that settlements were usually maintained for long periods of time and that primary refuse was brought to a predetermined location, where it then became secondary refuse. Scholars, however, prefer the term tertiary waste for this phenomenon because waste in such pits was the result of water's effect on the landscape; it was not until the Middle Ages that pits were intentionally dug for storing waste (Sommer, 1991, 101; Neustupný, 2007, 70).

Mining waste is another category of waste. There are many Neolithic sources of materials for producing chipped and ground stone tools in Central Europe, several of which have been studied, for example, the metabasite deposits in the Jizera Mountains that also feature a countless amount of occupation waste (cf. Š́da, 2007). In the Chalcolithic Age, the stone mining of the Neolithic Age continued, as the land was significantly exploited to gain the materials necessary for producing metals. Surface as well as underground mines have been discovered from both of these periods (Atkinson, 1987). Underground mines from the Neolithic and Chalcolithic Ages have been documented, for example, at the Polish site of Krzemionki, where more than 2,500 shafts where flint was mined have been found at depths ranging from five to nine meters (Bąbel, 2008). Gangue was deposited in no-longer operational shafts and thus this unneeded material was used for stabilizing the entire mine system. ${ }^{9}$ Another example is the Dutch Neolithic stone mine of Rijckholt. Mining and the subsequent processing of minerals resulted in the production of waste in the form of gangue and slag. We know about what is most likely one of the oldest copper-working sites in Europe (dating from the Neolithic Age) thanks to the discovery of slag, the waste resulting from smelting ore (Ruiz-Taboada \& Montero-Ruiz, 1999).

Mining and processing ore resulted in what was likely one of the earliest major environmental problems nearly 7,000 years ago in southern Jordan (Grattan et al., 2016). Slag containing excessive amounts of heavy metals contaminated the soil and water and was then consumed by humans. Analyses of skeletal remains with high lead and copper levels have confirmed that the long-term health problems, infertility, and early deaths that struck this community were the result of poisoning (Grattan et al., 2016). Waste water is another important category of waste that is produced, for example, as a result of personal hygiene practices or production methods.

\section{WASTE STRATEGIES}

The Skara Brae settlement on Scotland's Orkney Islands is of unique archaeological value, and not just for the study of waste. ${ }^{10}$ It is theorized that here every dwelling had a toilet ${ }^{11}$ and

\footnotetext{
${ }^{9}$ Henk Engelen Rijckholt Flint Mine. Available at http://www.vuursteenmijnen.nl/rijckholt/index.htm

${ }^{10}$ Skara Brae is likely the most well-preserved Neolithic village in Europe. It is also a UNESCO world heritage site.

${ }^{11}$ The discovery of moss at a settlement (if moist enough to have been preserved) could point to the presence of a latrine. Thanks to its antiseptic effects, moss was used similarly to how we today use toilet paper (Morton et al., 2010); it was even found on Ötzi, the Chalcolithic man found frozen in the snow of the Alps (Fowler, 2001).
} 
that there was a drainage system for the entire settlement (Kilroy, 1984). In general, defecation is one of the few bodily functions that can be documented through archaeological sources. At the Çatalhöyük site Ian Hodder hypothesizes that a latrine was located in the north-eastern part of residential spaces (even though one has been documented in only one house). After defecating, bodily waste was taken out of the home and thrown on a dump (which formed middens) (Hodder, 2006). The stone houses were built into middens most likely for insulation and stability. As far as waste strategies are concerned, it is interesting to note that these stone houses were built into middens consisting of waste. ${ }^{12}$ These deposits are made up of practically all types of possible waste, but kitchen waste dominates. The insulation- and stability-providing middens of Skara Brae contain a high percentage of the remains of sea creatures (Childe \& Clarke, 1983). This waste strategy elegantly found a reuse for everyday refuse. Similar examples of waste-construction strategies have also been discovered at the Neolithic Scottish sites of Rinyo and Links of Noltland. In some cases the walls of Neolithic houses have been found to be made from a mass of organic waste. Thanks to radiocarbon dating we know that this waste was several generations old (Ritchie, 1983). As Thomas (2002) notes, the denizens of these houses most likely did not view this "waste" material as something they wanted to get rid of. Thus, this material can be considered rubbish following Thompson's definition of the term (Thompson, 1979).

At Ness of Brodgar, another Orkney Islands site, one midden measures up to five meters in height and is the largest Neolithic waste structure ever found in all of Britain. Waste was deposited outside of the village's massive stone walls; researchers hypothesize that this dump, besides having a practical use, could have also served as a ceremonial site somehow related to the transformation of waste that occurs in decomposition or as a symbol of the abundance of resources/property (Card, 2011). ${ }^{13}$ It has already been demonstrated that in the Neolithic organic material from dumps was later applied to the soil to increase crop yields (Simpson et al., 2006).

Petr Květina has studied Neolithic non-ceramic waste from a Linear Pottery culture site in Bylany u Kutné hory, Czech Republic. He focused on chipped tool production, ground tool production, stones, polishing stones, quern stones, and the context in which this refuse was deposited nearby houses (Květina, 2010). He established the basic spatial (settlement, economic, and social) unit as a building complex consisting of one Neolithic house and one adjacent pit; these pits are located mainly to the east and west of buildings, although some can be found in the north, but none in the south. Otherwise, they are located within five meters from the likely location of the houses' walls (Květina, 2010).

The analysis of non-ceramic waste demonstrated that the more houses there were at the settlement the more non-ceramic waste there was, although in relative numbers there was less waste per house (Květina, 2010). This finding may indicate that families shared tools (if we assume that one family dwelled in each house). It is however likely that waste from inhabited houses was deposited in abandoned dwellings (Květina, 2010).

\footnotetext{
${ }^{12}$ In an extensive inquiry into hunter-gatherer societies anthropologist Richard B. Lee claims that on average only one-third of people's diets consisted of fresh meat, the richest and most sought-after source of fat and protein, and that people who had more meat were attributed greater prestige (1986). Thus, we can also theorize that the remaining two-thirds of people's diets consisted of wild fruits, vegetables, grains, nuts, and eggs.

${ }^{13}$ Lewis-Williams \& Pearce (2005) discuss in greater detail symbolism, ritual, and changing thought at the turn of the Paleolithic and Neolithic Ages.
} 
Due to the inherent nature of archaeological (i.e., physical) sources, the materials and the context in which they have been found may have been distorted by many cultural and natural processes. Besides abandoned buildings, pits served as secondary dumps, ${ }^{14}$ which were likely created for other purposes (as wells, for fruit storage, clay mining for mudbricks) (Květina, 2010).

Waste management elements typical for agricultural societies, but not hunter-gatherer ones, include activities that take place only in settlements - for example, discarding waste in courtyards, abandoned buildings, and pits, which were initially dug for other purposes (i.e., for extracting clay or stone) (Bar-Yosef \& Meadow, 1995). Waste pits were most likely filled quickly, as attested to by the homogeneity of their contents. Neolithic pits may have been used for more than just depositing waste; they also provided a suitable environment for storing food. Pit shape played an important role, and Thomas notes that the shape of Neolithic pits ${ }^{15}$ were likely unsuitable for storing food, unlike Iron Age conical pits (Thomas, 2002).

When interpreting deposited waste, it is important to keep in mind that some objects may have been discarded that were not considered to be waste. Cultural deposition processes are primarily dependent on how the given materials, artefacts, and ecofacts are classified (Moore 1986 in Thomas 2002). Here it is necessary to reflect on the work of Peters \& Schmidt (2004), who at Göbekli Tepe analyzed the composition of dumps and their bone percentage and compared them to the depictions of animals on stone steles.

Occupation debris in Neolithic structures and its interpretation is another category. Researcher Marie Zápotocká (2002) gives a colorful list of artefacts that were concentrated in a waste area. Among waste consisting of stone tool production debris, a large amount of bone material was also found (the presence of awls likely indicates the processing of leather). Zápotocká theorizes that workshops produced not only stone tools but also other implements as well, such as sheathes and sacks for storing artefacts, knife handles, hafts, and so on. Therefore, it seems likely a large spectrum of waste materials can be found in the debris from this workshop. Workshops, however, were not always located directly in settlements (Zápotocká, 2002). ${ }^{16}$

It is likely that a large amount of waste in the Neolithic and Chalcolithic Ages was "secondary refuse" (that is, waste intentionally deposited at a certain dump site ${ }^{17}$ outside a residential structure.) Such examples can also be likely documented from the Upper Paleolithic (Neustupný \& Vencl, 1995); however, between the Paleolithic and the Neolithic significant quantitative growth occurred largely as a result of the settled way of life and related technological advances.

\footnotetext{
${ }^{14}$ Julian Thomas (2002) mentions Neolithic waste pits in his work.

${ }^{15}$ They mostly contain ash, burnt chalk, and residual charred organic material (Thomas, 2002).

${ }^{16}$ Based on Binford's model of a "Men's Outside Hearth" (Binford, 1978), we can assume that waste which caused some kind of problem (being sharp, dangerous, or un-reusable) was deposited outside of the settlement or in some other way spatially confined so that its impact was minimized.

${ }^{17}$ Primary refuse is artefacts and ecofacts that were left "where they were" without any indication of a thought-out waste management system.
} 


\section{TELL SETTLEMENTS AND CONSTRUCTION WASTE}

As has already been mentioned, in some cases refuse was stored in uninhabited, abandoned houses. Based on the examples of Middle Eastern ${ }^{18}$ tells, ${ }^{19}$ we can observe a strategy used by people to adapt to the natural environment and at the same time likely used to deal with building waste. When an old house was rebuilt, ${ }^{20}$ it was left in its original location and a new house was built on the ruins; thus, over the course of centuries the ground level of the settlement was constantly rising. It is necessary to point out that this urban planning strategy for developing the earliest agricultural villages (the site of which was predetermined by the location of available water sources) in the Middle East could have helped mitigate the impacts of floods and in general create a safer raised environment with a better view of the surrounding land. The application of the tell settlement ${ }^{21}$ strategy created over the course of centuries a practically vertical settlement stratigraphy with layers that are arranged chronologically.

\section{The Middle East}

For studying waste management in the Neolithic it is necessary to describe some model cases from the Middle East. This region played a critical role in the initial stages of agriculture, plant breeding, and animal domestication. The Neolithic tell of Çatalhöyük in today's Turkey was selected as a model site. Çatalhöyük is one of the most important Neolithic sites, thanks to the highly precise archaeological research that has been conducted here by Ian Hodder in particular.

Considering the large population of this settlement - it is theorized that at one point in time 3,500 to 8,000 people might have lived here (Cessford, 1995) — dealing with waste was more complicated and likely required rules and organization. Ian Hodder writes that "the organization of discard and other activities was highly rule-bound" (Hodder, 2006; 103).

Population density and the architectural style of houses in which they were literally stuck to one another with no streets in between them did not make waste management an easy feat. It is assumed, however, that inhabitants had to engage in a significant level of cooperation to remove refuse, particularly human and animal fecal matter. Waste was likely deposited in the alleyways between buildings; Hodder speculates that these alleys were not used for walking but demarcated various "neighborhoods," which were perhaps based on family affiliation (Hodder, 2006) or on power structures.

Some middens are in open spaces and were used over long periods of time; others midden areas were found in abandoned houses. Considering the ratio of houses to midden areas, it is possible that middens that contain, for example, oven ashes, were shared for more houses (Hodder, 2006).

\footnotetext{
${ }^{18}$ To a much lesser extent, tells are also found in Europe, mainly in the East, from Hungary through the Balkans. They include Jászberény in Hungary and Karanovo in Bulgaria.

${ }^{19}$ The term tell can still be observed today in the names of some human settlements, such as Tel Aviv in Israel and Tel Afar in Iran.

${ }^{20}$ For example, as a result of generational change.

${ }^{21}$ Interestingly, a similar strategy that resulted in the artificial rising of terrain can be observed in Medieval towns located near rivers. Flowing water constantly clogged the channel with sediment and thus artificial fill was used to accommodate the changing landscape. The ground floors of Medieval houses are today below-ground cellars. Prague's old town in a spectacular example of this phenomenon.
} 
Although raw materials for producing chipped stone tools were prepared outside of dwellings in the vicinity of the source of the material (Hodder, 2006), the final modifications to stone tools were made in houses. Waste from this final phase of tool making was then gathered and disposed of in dumps (middens) (Carter et al., 2005 in Hodder, 2006).

External middens were used for extended period of time; the also contain entire carcasses, where as other waste deposit areas contain only certain faunal fragments. In contrast, middens in abandoned houses contain only certain bones, not entire skeletons, and more bones that indicate they have been digested. Based on the presence of these partially digested bones, Hodder theorizes that dogs were closed up in these abandoned buildings.

Thanks to the discovery of coprolites, we know that dumps contained fecal matter, including, most likely, that of humans. When it came to waste management, the inhabitants of Çatalhöyük clearly differentiated between the inner space of dwellings and the external environment. A quantitative analysis of the densities of all types of materials excavated across the entire site conducted by researcher Cross May (2005) indicates the greatest variation between refuse categories of midden, floor, and fill.

Overall, the buildings at Çatalhöyük were surrounded by deposits containing fecal matter and rotting organic waste. They must have posed health risks; they certainly attracted insects and emitted foul odors. At another Middle Eastern site, Aşıklı Höyük, one dump was located in the same place throughout the entire existence of the settlement (Cross May, 2005).

Based on the internal organization of dwellings at Çatalhöyük, we can infer something about how cleanliness was perceived. In all of the studied dwellings the floor is dirtier in the area around the oven and hearth (Hodder, 2006). In contrast, the area where ancestors were buried featured a cleaned, plastered surface. There is even a well-defined groove between the clean and dirty surfaces (Hodder, 2006). Hodder states that the dirty area was, with some exceptions, in the southern part of the building and was located near the ladder that provided entry from the rooftop. In the northern part of the building, chipped stone tools were produced along with a certain amount of debris. In contrast, the clean part of houses with plaster floors was as a rule in the north and feature less materials on the floor. Hodder also suggests that different parts of the building were made with different materials, which predetermined how certain parts of the house would be used; if this is the case, it would demonstrate clear evidence of a well-thought-out waste management system. A layer of plaster on the floors at Middle Eastern sites may have made keeping them clean easier. ${ }^{22}$ This plaster was made by mixing burnt and pounded limestone with water. The process was quite difficult. Some researchers think that the number of plaster layers may reflect the wealth of the homeowner (Bar-Yosef \& Meadow, 1995).

The examples from this site, however, cannot be generalized to cover the entire period; instead they were examples of how waste management solutions were devised to deal with local problems. Nonetheless, due to similarities in the material composition of waste produced in the Neolithic, certain similarities can be expected at other sites.

\section{Waste and odor}

Odors and waste are usually closely related. Although odor is a cognitive category that may be perceived and interpreted by various cultures and ethnicities differently, an objective perception of foul scents exists, which is based on biology. Our olfactory nerves can inform us of food quality or the environmental conditions that surround us. They help identify potential threats and force us to deal with them. Waste materials that emit odors, such as

\footnotetext{
${ }^{22}$ A similar example comes from the Romanian site of Uivar (Draşovean \& Schier, 2010; 180, p. 23). For a discussion of white plastering on daub, see also Lička \& Mach, 2013.
} 
various organic waste and animal and human fecal matter, predetermine where such waste will be discarded. Some waste materials emit strong odors and therefore clearly demarcated special areas on the peripheries of settlements were established for such waste. ${ }^{23}$

Polish researcher Pawłovska, who has studied odors at the Neolithic site of Çatalhöyük in Turkey, describes various activities that resulted in unpleasant scents, such as stabling animals, heating poorly ventilated houses ${ }^{24}$ waste management, and slaughtering animals.

Within the settlement itself waste was burnt and also deposited in dumps (middens). The dogs that Pawłovska claims were owned by every family might have helped dispose of food waste and bones. ${ }^{25}$ Stabled animals of course produced dung, which could be collected, dried, and used as heating fuel. In comparison with collecting the dung of wild animals (it has been theorized that this was done at Çatalhöyük), collecting the dung of domesticated animals $^{26}$ was much simpler (Pawłovska, 2014).

Abandoned homes were not used just for storing waste; they were also used as stables (Pawłovská, 2014). These structures likely had their own waste management system in place and were periodically and regularly cleaned to remove excess dung. In one of the buildings at Çatalhöyük a latrine was discovered; it was likely filled with straw to ease regular cleaning (Hodder, 2011). The disposal of unwanted material created deposits between houses, as well as in abandoned houses as mentioned above. The range of discarded objects indicates great diversity - this waste primarily includes human and animal bones, mollusk shells, eggs shells, small decorative items such as beads, obsidian, pottery, construction waste, charred plant seeds, charcoal, baskets, clay marbles, fecal matter, and sweeping debris (Hodder, 2006); the latter finding demonstrates that dwellings were cleaned and at the same time tells us something about the day-to-day life at this Neolithic tell settlement. When this waste was deposited (that is, before its organic competent, which usually is not preserved in the archaeological record, decomposed), this deposit must have consisted of a large amount of stinking organic matter (Pawłovska, 2014).

\section{THE POSSIBILITIES OF INTERPRETATION}

When interpreting archaeological finds, we must always bear in mind that artefacts may have undergone several post-deposit changes, which have the potential to fully redefine their interpretative value. Another problem is related to the "archaeology of the unfound." Objects that can be assumed to have been present are often not found, mainly due to the material nature of such artefacts (for example, organic objects can only be preserved in specific types

\footnotetext{
${ }^{23}$ The site of Kopal, which is in the immediate vicinity of Çatalhüyük, bears witness to this idea. Animals were slaughtered here. The carcasses that were intended for butchering were then transported to Çatalhüyük. Kopal was thus reserved for a specific type of activity, which may have also had a religious aspect (Pawłovská, 2014).

${ }^{24}$ The houses in Çatalhöyük had no windows and they were entered using a ladder through the roof.

${ }^{25}$ Vomited up, chewed up, and half-eaten bones are evidence of dogs in a settlement. Canine fecal matter was likely collected and deposited in a certain area (Pawłovská, 2014).

${ }^{26}$ This heating method is still practiced today. Dried dung is a valuable material that serves as both fuel and a natural fertilizer in places such as India and Africa. Ethno-archeological studies have documented the drying of dung both outside of dwellings (Yalman, 2005 in Pawłovská, 2014) and on their rooftops (Moreno-García \& Pimenta, 2011 in Pawłovská, 2014).
} 
of environments). Thus, it is likely that the need to defecate played a role in the arrangement of settlements; however, we have very little physical prehistoric evidence to prove it.

As far as depositing waste is concerned, we can find a certain parallel in Binford's book Nunamiut Ethnoarchaeology, in which he deals with hunting and processing prey. How much food was transported back to the settlement and how is largely dependent upon environmental conditions and hunting strategies. The difference between transporting an entire animal or just parts of it had implications for the overall waste management system because sometimes animals were cleaned, butchered, and even stored outside of the settlement (Binford, 1978). In such situations certain types of materials never make it into settlement waste (and subsequently into archaeological material), even though such material played an important role in living culture. However, due to the nature of archaeological sources they do not tell us about living culture. However, with the help of ethno-archeology we can assume the causalities of various phenomena. Interpretation and its validity is always dependent on the context of the entire situation.

A certain problem is presented by the classification of waste as a specific category in terms of technology and artefact typology; such classification is often based on the subjective approach of every researcher. For example, some researchers might identify a stone flake as waste, whereas others see it as a blade. Such reclassification has taken place in studies on the Upper Neolithic settlement of Jezeřany-Maršovice (Přichystal - Svoboda, 1997; Oliva, 2001).

\section{CONCLUSION}

The continuity of waste management areas at Neolithic settlements was strictly maintained and reflects the collective aspect of waste management of each settlement, which played an important role in the life of the settlement. We can observe fluidity between public space and private ownership from one example where a house was built on a public dump (Hodder, 2006). Deposits contain many small waste units ranging from ashes to sweeping debris and thus we can characterize dumps as a full context made up of many smaller, individual situations (Hodder, 2006).

Schiffer assumes that with increasing settlement size the distance an artefact must travel to be disposed of also grows (Schiffer, 1976). Thomas, ${ }^{27}$ however, objects to Schiffer's behaviourism and, riding the wave of post-processualism, calls for greater emphasis on the influence of culture and individualism on how people of certain cultures deal with waste (Thomas, 2002) and the fact that these processes are not dependent on generally valid rules, but that they differ from culture to culture. Cultural rules are facultative and self-regulating and evolve based on current circumstances. In other words, we could say that cultural variability is the result of how different societies utilize the environment.

To a certain extent, both of these hypotheses can be accepted as true. In the broadest terms, our relationship to waste is framed by biology. To these biological rules, however, were later added several "artificial" rules and measures that are extensions of these biological rules in their dependence on environmental and cultural affiliation. Thomas, in further opposition to Binford's "New Archeology" assumes that the deposition of waste is affected more by cultural processes than natural ones (Thomas, 2002). In other words, these processes cannot be generalized to any great extent, and therefore not even ethnographic evidence can be

\footnotetext{
${ }^{27}$ Like Thomas, Hodder, too, objects to Schiffer. Based on research conducted in Baringo, Hodder discovered that material culture does not often directly reflect human behavior, but more the transformation of behavior. (Hodder \& Hutson, 2003).
} 
applied as a direct parallel to prehistoric waste management. However, on the basis of such parallels we can theorize that in prehistoric times one single, homogenous category of waste did not exist. Classifications of the material world are not culturally static; instead activities and relationships within communities are influenced by constant change (Thomas, 2002). The principle of cleanliness varies from place to place and over time. Neolithic people's attitude towards waste is much different than our contemporary view of it (Thomas, 2002).

The relationship between waste and social organization is also dependent on a given society's view of dirtiness. Thus, a short-lived settlement may have a well-organized waste management system, and in contrast a long-lived settlement might have no such thing (Hodder \& Hutson, 2003).

\section{REFERENCES}

Atkinson, R. L. (1987). Copper and copper mining. Shire Publications.

Bar-Yosef, O., \& Meadow, R. H. (1995). The origins of agriculture in the Near East. In Douglas Price, T. \& Gebauer, A. B. (Eds.) Last hunters, first farmers: New perspectives on the prehistoric transition to agriculture (pp. 39-94). School of American Research Press.

Bąbel, J. T. (2008). Krzemionki Opatowskie the earliest beginnings of modern mining. The mine as a witness to history and a monument of technology, 21.

Binford, L. R. (1978). Nunamiut Ethnoarchaeology. Academic Press, New York.

Bocquet-Appel, J. P., \& Bar-Yosef, O. (Eds.). (2008). The Neolithic demographic transition and its consequences. Springer Science \& Business Media.

Bulmer, R. (1976). Selectivity in hunting and in disposal of animal bone by the Kalam of the New Guinea Highlands. Duckworth.

Card, N. (2011). Ness of Brodgar. Discovery and Excavation in Scotland, 12, 140-1.

Cauvin, J., \& Watkins, T. (2000). The Birth of the Gods and the Origins of Agriculture. Cambridge University Press.

Carter, T., Conolly, J., \& Spasojević, A. (2005). The chipped stone. In Hodder, I. (Ed.). Changing materialities at Çatalhöyük: Reports from the 1995-99 seasons. Vol. 5. (pp. 221-284.). McDonald Institute for Archaeological Research/British Institute of Archaeology at Ankara Monograph, Cambridge.

Cessford, C. (1995). Estimating the Neolithic population of Çatalhöyük. In Hodder, I. (Ed.) Changing materialities at Çatalhöyük: reports from the 1995-99 seasons. Vol. 4. (pp. 323-326). McDonald Institute for Archaeological Research/British Institute of Archaeology at Ankara Monograph, Cambridge.

Childe, V. G., \& Clarke, D. V. (1983). Skara Brae. HMSO.

Cross May, S. (2005). Statistical integration of contextual data. In Hodder, I. (Ed.) Changing materialities at Çatalhöyük: reports from the 1995-99 seasons, Vol. 5. (pp. 23-44.). McDonald Institute for Archaeological Research/British Institute of Archaeology at Ankara Monography, Cambridge.

Draşovean, F., \& Schier, W. (2010). The Neolithic tell sites of Parţa and Uivar (Romanian Banat). A comparison of their architectural semence and organization of social space. In Hansen, S. (Hrsg.) Leben auf dem Tell als soziale Praxis (pp. 165-187), Bonn.

Fowler, B. (2001). Iceman: uncovering the life and times of a prehistoric man found in an Alpine glacier. University of Chicago Press. 
Grattan, J. P., Adams, R. B., Friedman, H., Gilbertson, D. D., Haylock, K. I., Hunt, C. O., \& Kent, M. (2016). The first polluted river? Repeated copper contamination of fluvial sediments associated with Late Neolithic human activity in southern Jordan. Science of The Total Environment, 573, 247-257.

Guttmann, E. B., Simpson, I. A., Davidson, D. A., \& Dockrill, S. J. (2006). The management of arable land from prehistory to the present: case studies from the Northern Isles of Scotland. Geoarchaeology, 21(1), 61-92.

Havlíček, F. (2015). Waste Management in Hunter-Gatherer Communities. Journal of Landscape Ecology, Vol. 8, 47-59.

Havlíček, F. (2017). Waste management and purity in central Europe in the Middle Ages. (in press).

Hložek, M., Tichý, R., Dohnálková, H., \& Dohnálková, I. (2006). Implications of crushed pottery in prehistoric pottery. EuroREA 3/2006, 7-10.

Hodder, I., \& Hutson, S. (2003). Reading the past: current approaches to interpretation in archaeology. Cambridge University Press.

Hodder, I. (1987). The meaning of discard: ash and domestic space in Baringo. In Kent, S. (Ed.) Method and theory for activity area research: An ethnoarchaeological approach, (pp. 424-448.) Columbia University Press.

Hodder, I. (2006). The leopard's tale: revealing the mysteries of Çatalhöyük. Thames \& Hudson.

Hodder, I. (2011). An archeology of the self: the prehistory of personhood. In Wentzel van Huyssteen, J, \& Wiebe, E. P. (Eds.) Search of Self: Interdisciplinary Perspectives on Personhood (pp. 50-69), Michigan/Cambridge.

Hayden, B., \& Cannon, A. (1983). Where the garbage goes: refuse disposal in the Maya Highlands. Journal of anthropological archaeology, 2(2), 117-163.

Kilroy, R. (1984). The Compleat Loo. Salamander Books. London.

Květina, P. (2010). The spatial analysis of non-ceramic refuse from the Neolithic site at Bylany, Czech Republic. European Journal of Archaeology, 13(3), 336-367.

Lee, R. B. (1968). What hunters do for a living, or, how to make out on scarce resources. In Lee, R. B., DeVore, I., \& Nash, J. (Eds.) Man The Hunter, 30-48.

Lewis-Williams, D., \& Pearce, D. (2005). Inside the Neolithic mind: Consciousness, cosmos, and the realm of the gods. Thames \& Hudson.

Lička, M. \& Mach, Z. (2013). Mazanicový sídlištní odpad jako zdroj informací o neolitických jednokomorových pecích. In: Cheben, I. \& Soják, M. (eds.), Otázky neolitu a eneolitu našich krajín - 2010. Zborník referátov z.29. pracovného stretnutia bádatel'ov pre výskum neolitu a eneolitu Čiech, Moravy a Slovenska. Vršatské podhradie, 27. - 30. 9. 2010. Nitra, (pp. 153-172.

Martin, P. S. (1984). Prehistoric overkill: the global model. In Martin, P. S. \& Klein, R. G. (Eds.) 'Quaternary Extinctions: a Prehistoric Revolution', (pp. 354-403).

Mithen, S. (2011). After the ice: a global human history, 20,000-5000 BC. Weidenfeld \& Nicolson.

Moore, H. (1986). Space, text and gender: an anthropological study of the Marakwet of Kenya. CUP Archive. 
Moreno-García, M., \& Pimenta, C. M. (2011). Animal dung: rich ethnographic records, poor archaeozoological evidence. Ethnozooarchaeology. The present and past of human-animal relationships. Oxbow Books. Oxford, 20-28.

Morton, E., Winters, J., \& Smith, L. (2010). An Analysis of Antiseptic and Antibiotic Properties of Variously Treated Mosses and Lichen. University of Michigan.

Murdock, G. P. (1945). The common denominator of cultures. In R. Linton (Ed.) The science of man in world crisis, (pp. 20-25), New York: Columbia University Press.

Neustupný, E., \& Vencl, S. (1995). Formal methods at Hostim. In Vencl, S. (Ed.) Hostim. Magdalenian in Bohemia, Památky archeologické-Supplementum, 4. (pp. 205-224).

Neustupný, E. (1996). Poznámky k pravěké sídlištní keramice. Archeologické rozhledy XLVIII, 490 - 509.

Neustupný, E. (Ed.). (1998). Space in prehistoric Bohemia. Institute of Archaeology, Academy of Sciences of the Czech Republic.

Neustupný, E. (2007). Metoda archeologie. Plzeň.

Oliva, M. 2001: Sídliště lidu s moravskou malovanou keramikou v okolí Krumlovského lesa a jejich štípané industrie. In: Otázky neolitu a eneolitu našich zemí, Mostkovice 14. - 17. zář́ 1999. Pravěk Supplementum 8. Brno, (pp. 197-231).

Olsen, B. (2010). In defense of things: archaeology and the ontology of objects. Rowman Altamira.

Pawłowska, K. (2014). The smells of Neolithic Çatalhöyük. Turkey: Time and space of human activity. Journal of Anthropological Archaeology. Vol. 36. 1-11.

Peters, J., \& Schmidt, K. (2004). Animals in the symbolic world of Pre-Pottery Neolithic Göbekli Tepe, south-eastern Turkey: a preliminary assessment. Anthropozoologica, 39(1), 179-218.

Přichystal, A. \& Svoboda, J. (1997). Výroba štípané industrie na sídlišti kultury s moravskou malovanou keramikou v Jezeřanech - Maršovicích, Přehled výzkumů 1993-1994, 15-25.

Ritchie, A., et al. (1983). Excavation of a Neolithic farmstead at Knap of Howar, Papa Westray, Orkney. In Shepherd, I. A. G. (Ed.) Proceedings of the Society of Antiquaries of Scotland, Vol. 113, (pp. 40-121). National Museum of Antiquities of Scotland.

Richerson, P. J., Boyd, R., \& Bettinger, R. L. (2001). Was agriculture impossible during the Pleistocene but mandatory during the Holocene? A climate change hypothesis. American Antiquity, 66(3), 387-411

Ruiz-Taboada, A., \& Montero-Ruiz, I. (1999). The oldest metallurgy in western Europe. Antiquity, 73(282), 897-90

Simpson, I. A., Guttmann, E. B., Cluett, J., \& Shepherd, A. (2006). Characterizing anthropic sediments in north European Neolithic settlements: an assessment from Skara Brae, Orkney. Geoarchaeology, 21(3), 221-235.

Schiffer, M. B. (1976). Behavioral archeology. Studies in Archaeology. New York/London: Academic Press.

Schiffer, M. B. (1987). Formation Processes of the Archaeological Record. University of New Mexiko Press, Albuquerque.

Sommer, U. (1991). Zur Entstehung archäologischer Fundvergesellschaftungen. Versuch einer archäologischen Taphonomie. Studien zur Siedlungsarchäologie I., Universitätsforschungen zur prähistorischen Archäologie Band 6. Bonn. 
Šída, P. (2007). Využivání kamenné suroviny v mladší a pozdní době kamenné. Dílenské areály v oblasti horního Pojizeří. Dissertationes Archaeologicae Brunenses/Pragensesque 3. Praha-Brno.

Thomas, J. (2002). Understanding the neolithic. Routledge.

Thompson, M. (1979). Rubbish theory: the creation and destruction of value. Oxford University Press.

Vaquero, M. (2012). Temporal nature and recycling of Upper Paleolithic artifacts: the burned tools from the Molí del Salt site (Vimbodí i Poblet, northeastern Spain): Journal of Archaeological Science 39(8), 2785-2796.

Verhart, L., \& Wansleeben, M. (1997). Waste and prestige: the Mesolithic-Neolithic transition in the Netherlands from a social perspective. Analecta Praehistorica Leidensia, 29, 65-73.

Yalman, E. N. (2005). Settlement logic studies as an aid to understand prehistoric settlement organization: ethnoarchaeological research in Central Anatolia. In: Hodder, I. (Ed.) Inhabiting Çatalhöyük: Reports from the 1995-99 seasons, Vol. 4. (pp. 329-342). Cambridge: McDonald Institute for Archaeological Research.

Zápotocká, M. (2002). K interpretaci dílenského odpadu v neolitických objektech. In Neustupný, E. (Ed.) Archeologie nenalézaného, sborník prátel, kolegů a žáků k životnímu jubileu Slavomila Vencla, Plzeň, (pp. 291-299). 